\title{
Inequalities and Inclusive Development; Some Policy Perspectives for Indian Economy
}

\author{
Tada Prabhakar Reddy \\ Centre for Planning, Monitoring and Evaluation, National Institute of Rural Development and Panchayati Raj, India
}

Received November 30, 2019; Revised March 10, 2020; Accepted March 19, 2020

Copyright $\mathrm{O} 2020$ by authors, all rights reserved. Authors agree that this article remains permanently open access under the terms of the Creative Commons Attribution License 4.0 International License

\begin{abstract}
Government of India emphasized inclusive growth and the strategy was achieving a particular type of growth process which will meet the objectives of inclusiveness and sustainability. The strategy was based on sound macroeconomic policies which establish the macroeconomic preconditions for rapid growth and support key drivers of growth. It includes sector specific policies and the institutional environment in which it occurs, achieves the objective of inclusiveness. While focusing on inclusive development one may ignore the inequalities which will have significant implications for growth and macroeconomic stability. It can concentrate political and decision making power with few, lead to suboptimal use of human resources, cause investment reducing political and economic instability. Some degree of inequality may not be a problem in so far as providing the incentives for people to excel, compete, save and invest to move ahead in the life. But, high and sustained levels of inequality especially "inequality of opportunity" can entail large social costs. Against the background, objective of the paper is to examine the drivers of inequality and suggest some policy prescriptions for addressing the issue. Therefore, we have reviewed literature, collected data from secondary sources and analyzed for arriving at conclusions. Despite the efforts of Government, there are challenges in achieving inclusive development while the initiatives are like symptomatic treatment to a chronic disease. Hence the following are suggested; Tax-GDP ratio has to be improved by broadening the tax base, raising corporate taxes and withdrawing sops and benefits to the Corporates. Social sector expenditure on health and education should go up. Labour laws need to be flexible so as to help the workforce as the rigid labour laws are acting as stumbling blocks for labour welfare in various sectors. Finally, implementation of gender budgeting should be enforced as a mandate for the governments.
\end{abstract}

Keywords Inequality, Inclusive Development, TaxGDP Ratio, Labour Laws, Social Sector Expenditures

\section{Introduction}

Eleventh Five Year Plan (2007-12) emphasized 'inclusive growth' and the strategy was aimed at achieving a particular type of growth process which will meet the objectives of inclusiveness and sustainability. The strategy was based on sound macroeconomic policies which establish the macroeconomic preconditions for rapid growth and support key drivers of growth. It includes sector specific policies and the institutional environment in which it occurs, achieves the objective of inclusiveness. However, there are challenges in achieving inclusive development while the initiatives are suffering from lack of coordination, adequate resources and manpower etc. Therefore, the best efforts of Government of India with its schemes and flagship programmes did not yield expected results towards inclusive development.

It is important to mention that there is a trade-off between inclusiveness and inequalities which are influencing each other in the development process. While focusing on inclusive development one might ignore the inequalities taking place in a country like India which will have significant implications for growth and macroeconomic stability. Inequalities can concentrate political and decision making power in the hands of a few, lead to a suboptimal use of human resources, cause investment reducing political and economic instability. Some degree of inequality may not be a problem in so far as providing the incentives for people to excel, compete, save and invest to move ahead in the life. However, high and sustained levels of inequality especially "inequality of opportunity" can entail large social costs. Besides, entrenched inequality of outcomes can significantly undermine individual's health, educational and occupational choices among others. Against the background, objective of the study is to understand the 
drivers of inequalities and explore the possible measures for ensuring inclusive development in India.

\section{Inequalities}

The structure ${ }^{1}$ of Indian society is characterized by abject poverty, skewed land distribution with minimal rights to women, gender subordination, powerlessness, and glaring inequalities in terms of income and wealth reflecting the widening gap between the rich and poor. On the other hand, the government is focusing on GDP growth rate while pursuing neo liberal economic policies with minimal social protection to the marginalized sections leading to further inequalities in the society and wealth creation by handful of people wherein the political and economic power is concentrated. It is a known fact that when neo liberal economic policies ${ }^{2}$ are adopted it is bound to affect adversely the poorer sections in terms of lack of opportunities, while they are plenty for the richer sections creating a wide gap between haves and have-nots. It is relevant to mention here Picketty's central thesis viz., 'Capital in the Twenty First Century' which argued that it's not just inequality of wealth and income that we are struggling with, but 'inequality of opportunity' which is of far more concern. In essence, he is arguing that wealth reliably leads to wealth. Everything else is chancy. The middle class is playing the economic lottery to improve their lot in life, while the wealthy have a sure thing. In fact, Picketty wants to change the lever on income inequality by putting a tax on wealth- not on income, which is the stuff of the middle class, but on fortunes themselves, on the money that is invested and reinvested and compounded and grown.

\section{Agriculture}

As regards the inequalities in agricultural sector, the Agricultural Census 2015-16 confirm the persisting trend of fragmentation of landholdings and their skewed distribution across size classes. The total area under farming in India declined from 159.59 million hectares in 2010-11 to 157.14 million hectares in 2015-16. At the same time the number of operational holdings increased by 5.33 per cent from 138 million in 2010-11 to 146 million in 2015-16. Therefore, the average size of operational holdings in India declined from 1.15 hectares to 1.08 hectares. It shows that there has been a proliferation of small and marginal landholdings since the last agricultural census in 2011. In 2015-16, about 86.21 per cent of the

\footnotetext{
${ }^{1}$ The structure of Indian society is characterized by a variety of inequalities while some are described here.

${ }^{2}$ The sectors hitherto meant for government alone are liberalized and opened for foreign direct investment in the name of economic reforms at the cost of domestic entrepreneurs and business people.
}

landholdings in the country consisted of small and marginal holdings (0-2 hectares) while their share in the operated area was only 47.34 per cent. The average size of small and marginal holdings was just 0.6 hectares the majority of which were in poorer states such as UP and Bihar. Semimedium holdings (2-4 hectares) made up 9.45 per cent of the total but the share in the operated area was 23.65 per cent. Medium holdings (4-10 hectares) constituted 3.76 per cent however, the share in the operated area was 19.96 per cent while the large holdings (10 hectares and above) comprised only 0.57 per cent but operated a share of 9.04 per cent of the total area. The Census also reveals that Scheduled Caste (SC) groups operated only about 9 per cent of the total available area and that the average size of their holdings was 0.78 hectares. Further, about 92 per cent of holdings operated by SC groups comprised small and marginal holdings (EPW, 2018).

Besides, the income of marginal, small and semimedium farmers is lesser than the monthly expenditure resulting in loans and they are indebted. The conclusions of National Commission for Enterprises in the Unorganized Sector (2008) ${ }^{3}$ report are relevant even today which says "consumption expenditure of marginal and small farmers exceeds their estimated income by a substantial margin and presumably the deficits have to be plugged by borrowing or other means" (p.12). The report also indicates that the poverty for small holding farmers is much higher than other farmers. Hence the need for increase in productivity and incomes of small holdings and promotion of non-farm activities for these sections of farmers are obvious.

According to National Sample Survey, 2013 the farm families with 0.01 to 2.0 hectares of land are able to get only Rs.4700-7400 monthly income. On the other hand, their annual income is in the range of Rs. $57,000-90,000$ which is not adequate for meeting their basic necessities like food and shelter, while health and education is beyond their capacity.

\section{Income and Wealth Inequalities}

In fact, wealth has been rising in India but not everyone has shared in this growth. There is still considerable wealth poverty reflected in the fact that 91 per cent of the adult population has wealth below USD 10,000. At the other extreme, a small fraction of the population ( 0.6 per cent of adults) has a net worth over USD 100,000. However, owing to India's large population, this translates into 4.8 million people. Credit Suisse report mentioned that 3400 adults have wealth over USD 50 million, and 1500 have more than USD 100 million (Global Wealth Report, 2018). Further, a

${ }^{3}$ The report of NCEUS, 2008 is valid even today given the agricultura situation more importantly, the small holder agriculture in India (which includes marginal, small and semi-medium farmers) as their situation has worsened further. 
bunch of young businessmen joined the group of Rs. 25 crores and above category last year.

Besides, the National Sample Survey data on consumption expenditure of bottom 40 per cent rural population in India showed a decline from 60.4 per cent to 55.1 per cent during 1999- 2000 and 2011-2012 ${ }^{4}$. All these suggest that rising inequalities in India while rapid reforms are followed by pushing growth rate agenda on the other. Therefore, it was suggested by development economists that the governments should offer social protection measures along with pro-poor policies and programmes aiming at marginalized sections. According to a recent report, only 45 per cent of the global population is effectively covered by at least one social benefit, while the remaining 55 per cent are left unprotected (World Social Protection Report, 2017-19).

Guy Ryder, ILO Director General opined that "the lack of social protection leaves people vulnerable to ill-health, poverty, inequality and social exclusion throughout their lifecycle. Denying this human right to substantial number of people is a significant obstacle to economic and social development. While many countries have come a long way in strengthening their social protection systems, major efforts are still necessary to ensure that the right to social protection becomes a reality for all".

On the other hand, the Indian government is grappling with the couple of key issues viz., corporate tax avoidance and the illicit financial flows which is a real challenge that requires strong political will to address the issue. As a matter of fact, the present government has claimed that their commitment in addressing the above two issues has been resolved through 'demonetization' which would result in massive mobilization of resources to the economy leading to less corruption in the coming years.

It is a fact that the scourge of inequality is rising rapidly in India and creating havoc with the lives of poor people in accessing many opportunities be it good education or health care or ration through public distribution system or decent employment in non-farm and off-farm sectors etc. The rapidly rising inequality in India is a great threat to the social cohesion and a challenge to all of us. It affects institutions adversely and dampens economic growth among others. Hence, understanding the extent of inequality if not measurement, and its drivers would be of significance for public policy for reducing inequalities and concomitant implications which are relevant to India. Therefore, the present attempt assumes significance in understanding the drivers of inequality and arriving at policy prescriptions which can address the same.

\section{Theoretical Underpinnings}

Inequality may be a signal of lack of income mobility and opportunity- a reflection of persistent disadvantage for marginalized sections of the society. Widening inequality has significant implications for growth and macroeconomic stability; it can concentrate political and decision making power in the hands of a few, lead to a suboptimal use of human resources, cause investment reducing political and economic instability. Some degree of inequality may not be a problem in so far as providing the incentives for people to excel, compete, save and invest to move ahead in the life. However, high and sustained levels of inequality especially 'inequality of opportunity' can entail large social costs (IMF, 2015). Besides, entrenched inequality of outcomes can significantly undermine individual's health, educational and occupational choices resulting in low level of social indicators. This called for growth at a rapid pace that would provide adequate attention to the welfare of the poorest sections (Pulin B Nayak, 2016).

As a matter of fact, the tax and transfer policies with redistributive justice would certainly diminish the inequalities but we need the commitment and dedication of the government in doing so. Tackling inequality through tax and transfer policies do not harm growth provided these policies are well designed with a pro-poor approach and implemented effectively. Further, redistribution efforts through social sector spending and labour market reforms should focus on families with children (and girls) as this is where key decisions on human capital investment are made and should promote skills development and learning across people's lives.

\section{Extent of Inequality}

While 1 per cent of population is controlling about 60 per cent of resources 99 per cent of population is utilizing 40 per cent of resources. At a micro level, while one is flooded with crores of rupees and capturing political power while sizeable population is living in abject poverty. Besides, the land is distributed in an uneven manner wherein more than 50 per cent of population is still dependent for their sustenance; lack of opportunities and facilities to many among others. The trickle-down effect has given less than expected results and it is a question of distribution of resources by the government.

The situation is such that we are not able to ensure the labour receive living wages, women and girls get their due share in the development trajectory and the rich being taxed based on their affordability among others. Besides, the public spending on health, education and agricultural extension etc., are woefully very low reflecting the inequalities in the society (N C Saxena, 2012). According to one study there has been an inequality, measured by Gini coefficient, in the distribution of consumption expenditure 
between rural and urban areas during 1970-71 to 2009-10 (D Jayaraj and S Subramanian, 2012). Further, the study argued that there is a sudden spurt in urban India in $2000 \mathrm{~s}$ in mean per capita consumption expenditure plausibly owing to liberalized economic policy and increases in government salaries following the implementation of the recommendations of two pay commissions of the government. As a result, the prevalence of rural, urban disparities in terms of consumption expenditure has been further widened.

Therefore, it is important to examine the inequalities in relation to socio-economic variables that are considered to be crucial for human development in any country. While trying to understand the extent of inequality we are doing a sort of situation analysis of inequalities with a broad brush paint approach.

\section{Gender Inequality}

According to World's Women 2015 report women constitute nearly two-thirds of all non- literates in the world and a proportion that has remained unchanged for the past 20 years. Of the 781 million adults over the age of 15 estimated to be non-literate, 496 million were women and women made up more than half the non-literate population in all regions of the world. Given the sizeable non-literate women population it is easy to understand that their employment and income levels would be at low leading to gender inequalities in the society. Besides, India had 270 million persons below the (Tendulkar) poverty line in 2011-12 as compared to 407 million in 2004-05, that is a reduction of 137 million persons over the seven years period. However, there are studies which argue that while the poverty is getting reduced on the one hand, there are others, especially women, who are falling into poverty due to other reasons.

The situation in India depicted that though 80 per cent of the agricultural operations are performed by women they are not considered as women farmers and do not possess land titles in their name. Despite several legislations women are not paid equal wages in many parts of India thus resulting in differences in incomes. As a matter of fact, women are disadvantaged in terms of their participation in the labour markets of developing countries. Women's earnings are lower, women's work is more likely to be informal, and women are disproportionately in casual positions. Today India is counted among the most important emerging economies of the world but employment conditions in the country still remain poor. The labour force to population ratio in the age group of 15 years and above is 56 per cent only compared to nearly 64 per cent for the rest of the world. The low participation of labour in India is largely because of the low female labour participation rate (31 per cent) which is amongst the lowest in the world and the second lowest in South Asia after

\section{Pakistan.}

The gap in male-female labour force participation is such that the LFPR for rural females of the age group over 15 years is only 35.8 per cent, while for rural males it is more than double at 81.3 per cent. The female labour force participation had a decadal fall from 36.7 per cent in 2005 to 26 per cent in 2018 with 95 per cent ( 195 million) women employed in the unorganized sector or in unpaid work (Empowering Women and Girls in India, Deloitte).

According to Oxfam Inequality Report 2018 the gender pay gap is 34 per cent in India that is, women get 34 per cent less compared to men for performing the same job with same qualifications which is based on its estimates on employment, unemployment survey (EUS) 2011-12 undertaken by the NSSO, ILO studies. The wage difference is lesser for more skilled workers and more for semi-skilled or unskilled workers. Across enterprise type, wage difference is less for government/public sector and public/private limited company. Large pay gaps in terms of average daily wages exist in male and female wage rates of casual and regular workers in rural and urban areas and the gap is narrower for regular workers in urban areas. On the other hand, for casual worker's wage gap is narrower in rural areas.

Inequality between women and men tends to be severe and highly visible in power and decision making arenas. In many parts of the country women hold only a minority of decision making positions in public and private institutions. Despite the advancement in occupying the coveted positions in local government women are still finding it difficult to take decisions collectively either for the village or for the household. Advances over the past two decades are evident in all the states but the progress has been slow.

Hence, gender based discrimination and inequality calls for immediate steps towards gender equality and gender just society wherein women and girls are able to access and control resources and get their due share of cake without any problem. Though the gender responsive budgeting introduced by the Government of India in 2015 it lacks commitment from various stakeholders. It should focus on public spending every year for women's welfare as against simple allocations and gender budget statement should be prepared and submitted by all the states as a mandated aspect.

\section{Taxation}

The tax-GDP ratio in Indian economy is 17.38 per cent during 2014-15 which further declined to 16.5 per cent during 2016-17 union budget. As a matter of fact, there is scope to enhance the tax-GDP ratio and adopt the progressive taxation policy. But the priorities for the redistribution should change in favour of bottom 40 per cent who are mainly poor and lower middle class in India whose taxpaying capacity is limited when compared to top 
10 per cent richer sections. The rate of taxes may be increased to that of rich in so far as direct and indirect taxes are concerned while reducing the burden of the same to the bottom 40 per cent whose incomes are minimal.

While increasing the tax base, adopting progressive taxation raising revenue is significant for public spending but the burden shouldn't fall on the bottom 40 per cent as their paying capacity is limited. Secondly, it is important not to burden the lower middle class who are just above the poverty line while taxing more on top 10 per cent of the pyramid helps in mobilizing the resources. It is important to mention here that addressing the avoidance of corporate taxation and tax incentives is critical in mobilizing resources for the economy in a substantial way.

Besides, every year tax incentives announced to Corporates by the Government of India is huge exceeding a one lakh of crores. On the other hand, there is an argument that the opportunity cost of 'tax breaks' given to Corporates would be higher had they been spent on health care and education to the poorer sections. Further, it is of urgent policy importance that the corporate tax avoidance and illicit financial flows have to be addressed on a war footing basis as they provide massive amount of resources to the economy making it a surplus budget economy.

Tax expenditure i.e., revenue foregone on account of tax exemptions and concessions offered for doubtful national benefits amounts to 4 to 5 per cent of GDP. Sudipto Mundle says that eliminating these two items of expenditure would free up fiscal space of about 10 per cent of GDP adequate to wipe out the entire combined fiscal deficit of the central and state governments and still allow for additional public capital spending amounting to 3-4 per cent of GDP.

Ironically various types of tax incentives continue to persist in spite of a number of studies questioning their effectiveness and highlighting their enormous costs. Many studies have revealed that such incentives are redundant and in many instances ineffective. They not only cause enormous loss of revenue but also introduce severe distortions in resource allocation, often without achieving the intended objectives. Even when they achieve the objectives there are better and lower cost methods of achieving them. As stated by Richard Bird and Eric Zolt ("Introduction to Tax Policy Design and Development", World Bank, 2003), factors such as stable governance system, sound macroeconomic policy and good infrastructure are more important in business location decisions than tax benefits. Further, Govinda Rao, a member of Fourteenth Finance Commission says tax incentives cannot compensate for the absence of these critical factors (Business Standard, January 21, 2013). Therefore, the following structural reforms are essential to ensure inclusive and all round development.

${ }^{5}$ The miniscule salaried class is paid lucrative salaries while in service and they are paid pension benefits in a substantial way after retirement whereas many are unemployed in the country and others are working for

\section{Tax-GDP Ratios}

The total tax revenue to the Indian economy is from two ways; direct and indirect taxes apart from non-tax revenues. As per 2014-15 (Budget Estimates) the revenue from direct taxes is 5.81 per cent to the GDP, while it is 11.57 per cent from indirect taxes and the total tax revenue is 17.38 per cent. According to Finance Ministry, Government of India the gross tax revenue is Rs. 19.11 trillion in 2017-18 whereas it is Rs. 17.10 trillion in 2016-17 fiscal year which registered a growth of 17 per cent compared to the last year. Nevertheless, the government is resorting to 'market loans' in a big way for filling the gap between total expenditure and total revenue. Instead it can concentrate on collection of corporate taxes from the companies which can mobilize huge resources and finance the social sector spending comfortably. As a result, the potential of raising resources from 'direct taxes' would improve as it falls under direct taxes category further, it can lead to equality. Second option is that the government can think of devising some ways wherein the burden of indirect tax can be minimized on the poor and lower middle class (the bottom 40 percent of the population) in Indian economy given their limited afford ability to pay. The measures include removing 'service tax' for instance on small hotels, establishments and businesses which directly benefit the poor, while giving exemptions for women in terms of 'stamp and registration fees' that can benefit women farmers in accessing land and homestead while bring in gender equality.

Besides the revenue foregone on account of tax incentives given to Corporates can be avoided as this amount to huge benefits which are not given to any other sector. While the revenue foregone for financial year 201617 (exclusive of additional tax due to MAT payment) was calculated at Rs. 130,184.41 crores. Taking into account the additional tax collected as a result of MAT, the actual revenue impact of tax incentives is higher at Rs. 86, 144.82 as against the tax expenditure of Rs. 83, 492.03 crores projected in the previous year. In fact, accelerated depreciation is the head under which the highest amount of tax incentive (Rs. 66,350.44 crores) has been given. Besides, across various sectors deductions availed by units located in Special Economic Zone, undertakings engaged in generation, transmission and distribution of power, undertakings engaged in development of infrastructure facilities and for production of mineral oil and natural gas accounted for a significant portion of the total tax incentive.

Another area of attention is pension and other retirement benefits. It is accounting for 10 per cent of revenue expenditure (non-developmental expenditure) of the Centre in 2014-15 (BE). In fact, it can be privatized so that the 
burden of managing those benefits is taken care of by the private sector effectively. As a matter of fact, we have to introduce the pension to the farming community and ensure retirement benefits to the workers of manufacturing and industry. Similarly, interest payments account for 50 per cent of revenue expenditure which is something huge burden on the economy. Both of these can be reduced with proper policies which can contribute to the process of equality.

\section{Social Sector Spending-Health}

There have been significant spending reductions across all parts of the health care sector while per capita health spending growth has slowed since 2009. On the other hand, the out of pocket expenses continued to grow since 2009 albeit at a slow rate. While many OECD countries, mostly European, have faced reductions in per capita health spending and growth has remained close to zero since 2009, China and Indonesia have seen health spending grow rapidly in line with the universal health coverage objective (table1). Brazil which spends a similar proportion of its GDP on health as OECD countries saw health spending continue to grow at 6 per cent per year between 2009 and 2011 while South Africa has seen health spending grow between 2 per cent and 6 per cent between 2009 and 2013 .

Table 1. Health Spending as a Percentage of GDP in BRICS Nations, 2013 (real terms)

\begin{tabular}{|l|l|l|}
\hline Country & Share of GDP & AAGR \\
\hline Brazil & 9.1 & 6.0 \\
\hline Russia & 6.5 & -0.2 \\
\hline India & 1.2 & n.a. \\
\hline China & 5.6 & 11.0 \\
\hline South Africa & 8.9 & 3.5 \\
\hline
\end{tabular}

Note; Average annual per capita growth in health spending 2009-13 Source; OECD Health statistics, 2015 July

Health expenditure as a percentage of GDP is just 1.4 per cent in 2014,in India, while small countries like Maldives (10.8), Marshall Islands (14.4), Austria (8.7), Micronesia (12.4), Tuvalu (16.4), Cuba (10.6) and Sweden (10) have generously spent so much money compared to India which has highest younger population in the world. However, the bigger countries like Canada, USA also registered with very good allocations on health expenditure ensuring the health of their citizens. It is a matter of prioritization of public expenditure; arresting leakages in government spending, enhanced expenditure on health with a focus on primary health care would go a long way in improving the health condition of people.

The public expenditure for health care and education is crucial in our country as bottom 40 per cent of the population is not able to access these from private sources. There are many studies which established the fact that the out of pocket expenses are very high when they approach private health care facilities in the absence of health insurance coverage (Reddy T.P, 2007). Besides, it was argued that in the absence of private investment, scaling up of public investment to improve the share of manufacturing sector in the economy from its present 16 per cent to 25 per cent and realizing the 'Make in India' is need of the hour (Balakrishnan P,2019).

Given the low level of health expenditure the health indicators depict a sad state of affairs in India. As per Sample Registration System 2013 data the infant mortality rate is 40 per 1000 children while neo-natal mortality rate is 28 per 1000 children which are high compared to other countries. Further, under five mortality rate is 49 and maternal mortality rate is 167 per lakh population in 2013. As a matter of fact, all these occur among poor families while rich families are able to access private health care facilities and lead a better life. Therefore, the effect of low level of spending on social sector falls on poor and lower middle class further exacerbating the inequalities between rich and the poor.

\section{Education}

According to the World Bank report education expenditure as a percentage of GDP in India was 4.3 per cent in 1999 which further declined to 3.35 per cent by 2012. While countries like Lithuania (17.7\%) Denmark $(8.5 \%)$ Ghana $(8 \%)$ and USA $(5.2 \%)$ have invested substantial budget in creating their own human capital.

As per District Information System for Education (DISE) indicators gender gaps persist in education at various levels of education in India. Number of girls for every 100 boys enrolled at primary level is 93, at upper primary level 95, at secondary level 90 and senior secondary level 89 in 2013-14. On the other hand, the dropout rates are high among ST (61.4 per cent) followed by SC (48 per cent) girls when compared to all girls(46.7 per cent) which is basically due to their socio-economic backwardness and cultural factors in some cases. However, the dropout rates among SCs are relatively less when compared to ST students denoting some better off situation among SCs. The students from other social categories are better off compared to ST and SC students in terms of dropout rates reflecting the inequality between haves and have-nots in pursuing education given the opportunity.

\section{Social Protection (SP)}

We are aware that the economic reforms will surely affect some sections of society who need benefits like pensions, scholarships, living wages and other benefits and finally in one word 'social protection' facilities. Though there are three types of instruments pertaining to social protection in India viz., social insurance, social assistance 
and labour market programs the first one is contributory while other two are financed by public funds. While gradually expanded the social protection programmes and begun to transfer funds to beneficiaries through Aadhaar linked bank accounts reducing likelihood of diversion of funds their coverage is limited.

The framework of social protection in India includes three main pillars viz., promotional, preventive and protective measures. Promotional measures aim at improving incomes both in the short to medium term through livelihood interventions and in the long term through human capital interventions. The key programs in this area to support investments in human capital include stipends, midday meals, and conditional cash transfers and targeted credit and livelihood programs for the poor. Preventive measures seek to avert deprivation prospectively by supporting households to manage different risks and shocks ex-ante. The main preventive instruments are public social insurance programmes for the unorganized sector. They include Rashtriya Swasthya Bhima Yojana, and Aam Aadmi Bhima Yojana etc.

Protective measures which provide relief against deprivation ex-post to the extent that the other two sets of measures fail to do so. This could address those falling into poverty as a result of shocks and/or for the chronically poor. The main protective public programs are Public Distribution System, Mahatma Gandhi National Rural Employment Guarantee Scheme, social pensions, employment programs for the urban poor (SJSRY) and targeted housing programs like Indira Awas Yojana for rural, Valmiki Ambedkar Awas Yojana (VAMBAY) for urban poor. In the private arena, such strategies would include sale of household assets, reduction in consumption, running down savings or taking children out of school.

Besides, it is evident from the 'Brazilian miracle' that the countries with cash transfer programmes in place are in a better position to provide protection to the most vulnerable but such programmes face the challenge of balancing effectiveness and efficiency. On the other hand, public works programmes can provide an effective safety net to the newly unemployed during a crisis.

However, the conspicuous absence of social protection in many sectors are making the poor vulnerable and resulting in less paid workers in the informal sector. As a matter of fact, social protection is generally weak in emerging economies leaving households highly vulnerable to shocks, while social protection schemes are often fragmented, their coverage and benefit rates are often too low and high informality limits the impact of traditional policy instruments (Oxfam India, 2018).

There are different experiences with the implementation of social protection programs across states. As regards the social protection programs performance (all-India) PDS which is highly appreciated as the best implemented program displayed 23.3 per cent of all households (BPL and APL) covered, while bottom quintile as percentage of total beneficiaries is 27 per cent during 2004-05 despite high awareness etc. When looked at MGNREGS, the coverage of relevant population is 33 per cent of rural households only despite substantial awareness generated about the scheme. The coverage (during 2004-05) of IAY is 12.8 per cent of rural households, National Old Age Pension Scheme (NOAPS) 8.3 per cent households with elderly, Swarnajayanthi Gram Swarojgar Yojana, Sampoorna Gramin Rojgar Yojana (SGRY, means universal rural employment programme) achieved only 0.8 per cent and 1 per cent of rural households respectively.

Besides programs which have wide coverage but are plagued by leakage of subsidies that limit the impact on the poor (e.g., PDS) while others which are well targeted and increasingly well designed but face a range of implementation challenges (e.g., MGNREGS) and still others which appear to be well designed and with systems for better implementation (e.g., RSBY). However, one of the main challenges in the implementation of social protection programs is lack of coordination and overlap in delivery of programs, both within and across levels of government, reduces accountability of those responsible for SP service delivery. Lack of financial and human resource capacity most notably, at the block and Gram Panchayat level but also at higher levels in terms of functions like strategic planning compounds the challenges of service delivery. As in many areas of service delivery in India, SP programs suffer from incomplete alignment of the " $3 \mathrm{Fs}$ " (functions, funds and functionaries) for a variety of reasons.

\section{Wage Inequality}

The violation of minimum wages under MGNREGS affects the incomes of the poor adversely and thus leading to income inequality over a period of time. Although equal wages are paid to men and women in MGNREGS they are less than the notified minimum wage rate. Hence, the demand for implementation of notified minimum wage rate which in fact needs to be enforced immediately.

It is clear from the above data that the wage inequalities persist which is nothing but the difference between notified minimum wage rate and the average wage rate paid and they are very high in the case of some states like Chandigarh, Telangana, Tamilnadu, Rajasthan and AP (table 2). Besides, it is worth mentioning that despite the legislations for equal wages, the wage inequalities are persisting in the informal sector where majority of people are engaged that need immediate attention from the policy makers (Oxfam India, 2019). 
Table 2. Violation of Minimum Wages in MGNREGS during 2017-18 (Rs)

\begin{tabular}{|c|c|c|c|}
\hline State & $\begin{array}{l}\text { Average wage rate paid per } \\
\text { day per person }\end{array}$ & Notified minimum wage rate & $\begin{array}{l}\text { Gap }=\text { notified minimum } \\
\text { wage- average wage }\end{array}$ \\
\hline Andhra Pradesh & 152 & 197 & 45 \\
\hline Arunachal Pradesh & 177 & 177 & 0 \\
\hline Assam & 183 & 183 & 0 \\
\hline Bihar & 177 & 168 & -9 \\
\hline Chhattisgarh & 166 & 172 & 6 \\
\hline Gujarat & 177 & 192 & 15 \\
\hline Goa & 240 & 240 & 0 \\
\hline Haryana & 278 & 277 & -1 \\
\hline Jammu\& Kashmir & 179 & 179 & 0 \\
\hline Jharkhand & 168 & 168 & 0 \\
\hline Karnataka & 236 & 236 & 0 \\
\hline Kerala & 261 & 258 & -3 \\
\hline Madhya Pradesh & 165 & 172 & 7 \\
\hline Maharashtra & 189 & 201 & 12 \\
\hline Manipur & 204 & 204 & 0 \\
\hline Meghalaya & 175 & 175 & 0 \\
\hline Mizoram & 194 & 194 & 0 \\
\hline Nagaland & 177 & 177 & 0 \\
\hline Odisha & 174 & 176 & 2 \\
\hline Punjab & 227 & 233 & 6 \\
\hline Rajasthan & 137 & 192 & 55 \\
\hline Sikkim & 179 & 177 & -2 \\
\hline Tamilnadu & 152 & 205 & 53 \\
\hline Tripura & 169 & 177 & 8 \\
\hline Telangana & 140 & 197 & 57 \\
\hline Uttar Pradesh & 175 & 175 & 0 \\
\hline Uttarakhand & 175 & 175 & 0 \\
\hline West Bengal & 171 & 180 & 9 \\
\hline Lakshadweep & 237 & 237 & 0 \\
\hline Puducherry & 180 & 205 & 25 \\
\hline Chandigarh & 183 & 265 & 82 \\
\hline
\end{tabular}

Source; ILO estimates based on NSSO data 


\section{Labour Market Reforms and Legislations}

Inclusive and well-functioning labour markets are central to delivering decent work and supporting social justice. This is because paid work is the main source of income for the vast majority of households worldwide and also because the organization of work can reinforce the core principles of equality, democracy, sustainability and social cohesion.

Although growth in India has improved substantially since 1991 economic reforms but the rate of good quality jobs has stagnated. India's labour legislation has become increasingly inflexible and restrictive over time. The costs imposed by such regulation forces businesses to continue in the informal or unorganized sector, wherein regulation is absent but social security is also non-existent. As a result, 93 per cent of the Indian workforce is employed in low quality and low paid jobs, with limited or minimal social security cover.

The labour structure under MGNREGS is more towards female workers while men are engaged in better employment elsewhere. The reason is that the work participation rate of females is higher in MGNREGS in some states like Rajasthan, Kerala and Tamilnadu reflect feminization of labour. However, the overall participation of female labour force has come down in the recent past which is a concern for all of us. Any central sponsored scheme has to be implemented with the help of local selfgoverning institutions (LSGIs) at the village level. Therefore, deepening democracy and strengthening decentralized governance for achieving sustainable development goals especially goal five gender equality and goal ten inequality is important.

When we look at the share of agriculture and allied sectors in GDP it is 13.9 per cent during 2013-14 while it is still employing more than 49 per cent of population in the country. However, when Central Statistical Organization released GDP data early 2015 the share of these sectors went up to 18 per cent in 2011-12 prices mainly due to base effect. Further, it was noted that the share of agriculture and allied sectors in GDP has gone up to 17.1 per cent during 2017-18 (provisional estimates) which is slightly lesser than previous year (17.9 per cent). On the other hand, the employment creation in agriculture is on the decline while it is constant in manufacturing sector which is supposed to increase over a period of time. This is where the 'jobless growth' is causing concern to most of us leading to inequalities in the economy.

Growing Informal Sector: A combination of slow and poor quality job creation has resulted in a bloated informal sector with poor productivity and security. The immediate reasons for a growing informal economy are increased taxes and social security contribution burdens, intensity of regulations and low quality of public sector services. Steadily increasing today about 93 per cent of the Indian workforce is employed in the informal sector out of a working population of over 400 million (Ministry of Labour and Employment, 2009). The high incidence of informality is a major challenge for the realization of decent work for all and sustainable and inclusive development.

As a matter of fact, informal employment refers to employment without legal and social protection- both inside and outside the informal sector. The informal economy on the other hand, refers to all units, activities and workers so defined and the output from them.

Since good quality formal employment is rare, access to it is extremely unequal. The disadvantaged social groups such as Scheduled Castes (SCs) Scheduled Tribes (STs) and large sections of the Other Backward Classes (OBCs) are mostly concentrated in low productivity sectors such as agriculture, construction and in low paying jobs as casual labourers while Muslims are concentrated in petty low productive self- employment. On the other hand, upper caste Hindus and others comprise minorities like Christians, Sikhs and Jains have a disproportionate share of good jobs and higher educational attainments. There is an overlap between poverty and poor quality of employment as well.

While global informal employment is 60 per cent, south Asia 77.4 per cent, it is 94 per cent in Indian economy denotes that the employment generation in the formal sector in Indian economy is very less. Further, it is to mention that the unemployment among urban youth in the age group of 15-29 years, who are looking for jobs, has been consistently rising for three quarters and was at 23.7 per cent in the December 2018 quarter, shows the Periodic Labour Force Survey (PLFS) data for 2017-18 released on 31 May 2019 by the Ministry of Statistics and Programme Implementation.

Table 3. Distribution of informal workers in India

\begin{tabular}{|c|c|c|c|}
\hline Year & Informal workers in informal sector (\%) & $\begin{array}{c}\text { Informal workers } \\
\text { In formal sector (\%) }\end{array}$ & $\begin{array}{c}\text { Total percent of informal workers in the } \\
\text { economy }\end{array}$ \\
\hline $1999-2000$ & 86.2 & 5.86 & 92.06 \\
\hline $2004-05$ & 86.3 & 6.37 & 92.67 \\
\hline $2009-10$ & 84.2 & 8.09 & 92.29 \\
\hline
\end{tabular}

Source; Papola and Sahu (2012) p. 41 
As a matter of fact, PLFS was launched with the objective of measuring employment every three months in urban areas and once a year in both rural and urban areas. The Quarterly survey only captures data classified as current weekly status (CWS) while the annual survey measures both the usual status and CWS.

A person who is unable to get work for even an hour in the last seven days despite seeking employment is considered unemployed under CWS. Under usual status the employment activity of a person is determined on the basis of a reference period of 365 days preceding the date of the survey. When measured by the usual status for 2017-18, male youth unemployment increased from 8.1 per cent in 2011-12 to 18.7 per cent while for females it rose to 27.2 per cent from 13.1 per cent in 2011-12.

Labour force participation or people working or looking for jobs in the age group of 15-29 years has been declining and touched 36.9 per cent in 2017-18. The rising unemployment rate despite falling labour force participation for the youth is more worrying.

\section{Conclusions and Policy Prescriptions}

From the foregoing discussion it is clear that the rapid reforms and rising inequalities are co-existing in India and creating widening gap between the rich and the poor and marginalized sections. The structure of Indian economy is characterized by income, wealth and gender inequalities which are deep-rooted, limited social protection measures with less than expected results, labour laws which are inflexible, very low social sector expenditure all call for a structural reforms towards achieving an equal society. It has been established that increasing public expenditure for health care and education is crucial in India as bottom 40 per cent of the population is not able to access these from private sources. Without public investment it would be difficult to achieve the inclusive growth and development that takes care of the needs of marginalized sections.

The absence of progressive taxation and prioritization of needs and allocations in Union budget have resulted in less than expected public expenditure on social sector is one real challenge faced by Indian economy. The labour legislations with its rigidity have contributed to the informalisation (and contractualisation) of labour with no social security coverage and protection to the employment is another reason for inequality. In all, it is a classic example of prosperity in the midst of poverty characterized by jobless growth in India which needs pro-poor public policy that encourages public expenditure. Secondly, preparation of budgets from below involving all stakeholders is critical in reducing inequalities in India given the population structure, their aspirations and the demographic dividend that we are expecting to realize in the future.
Therefore, it was argued that a four-fold approach to the problem would address the issue from its origin. They include;

- Tax-GDP ratio has to be improved by broadening the tax base, that every income earner pays tax, raising corporate taxes and withdrawing sops and benefits to the Corporates immediately.

- $\quad$ Public expenditure especially on health, education and skill enhancement should go up with a focus on women and girls. As a result, it will bring about drastic changes in improving the capabilities of individuals, availing opportunities, reducing inequalities and finally enhancing employment levels among marginalized sections thus leading to improvement in quality of life.

- Labour laws need to be flexible so as to help the workforce in receiving 'living wages' as the rigid labour laws are acting as stumbling blocks for the attainment of labour welfare in various sectors.

- $\quad$ Finally, implementation of gender budgeting should be enforced as a mandate for the governments and people should be involved in the budget preparation.

Then the goal of inclusive development becomes possible if the above measures are implemented scrupulously.

\section{Declaration}

The opinions expressed in the article are the author's personal views and they cannot be ascribed to the institution with which he is working.

\section{REFERENCES}

[1] Asit Ranjan Mishra (2019): "Unemployment on the rise among urban youth, finds survey”, Live Mint, 3 June, 2019

[2] Atul Sood (2016); "Politics of Growth; Script and Postscript", Economic and Political Weekly, July 16, Vol. LI No. 29

[3] Balakrishnan P (2019): "What a \$5 trillion economy would look like", The Hindu, 20th June

[4] Bina Agarwal (2003): 'Gender and Land Rights Revisited; Exploring New Prospects via the State, Family and Market', Journal of Agrarian Change, Vol.3., No.1 and 2 January and April

[5] Census of India, Ministry of Home Affairs, Sample Registration System (SRS), 2013, New Delhi

[6] Credit Suisse (2018): Global Wealth Report, October, 2018

[7] Dev S Mahendra (2012): Small Farmers in India; Challenges and Opportunities WP-2012-014, IGIDR, Mumbai June 
[8] Dev S Mahendra (2018): Transformation of Indian Agriculture; Growth, Inclusiveness and Sustainability, WP2018-026, IGIDR, Mumbai December

[9] Devesh Kapur and Prakirti Nangia (2015): Social Protection in India; A Welfare State Sans Public Goods? India Review, 14:1, 73-90 March

[10] Economic and Political Weekly (2018): "The Land Conundrum", Vol. 53, No. 42, $20^{\text {th }}$ October

[11] Government of India, Bureau of Planning, Monitoring and Statistics, MHRD (2014); Educational Statistics at A Glance, New Delhi.

[12] Government of India (2019): Statement of Revenue Impact of Tax Incentives under the Central Tax System: Financial Years 2016-17 and 2017-18, Receipt Budget, 2018-19, New Delhi

[13] Government of India, Ministry of Finance (2018): Economic Survey, 2017-2018, Department of Economic Affairs, January, Vol. 1

[14] Government of India: Report of National Commission for Enterprises in the Unorganized Sector, (NCEUS) 2008

[15] Institute for Human Development (2014): India, Labour and Employment Report, Workers in the era of Globalization, Academic Foundation

[16] International Monetary Fund (2015): Causes and Consequences of Income Inequality: A Global Perspective, Staff Discussion Note, June

[17] Jayaraj, D and Subramanian, S (2012): "On the Interpersonal Inclusiveness of India's Consumption Expenditure Growth", Economic and Political Weekly, November, 10 Vol. XLVII No.45

[18] N C Saxena (2012): Presentation in Skoch group meetings, New Delhi (mimeograph)

[19] OECD (2014) 'Focus on Inequality and Growth' Directorate for Employment, Labour and Social Affairs, December

[20] OECD (2018): Health Statistics 2018, July

[21] Oxfam India (2018): India Inequality Report, 2018, Widening Gaps, New Delhi

[22] Oxfam India (2019): Mind the Gap; State of Employment in India 2019, New Delhi

[23] Planning Commission, Government of India (2008): Eleventh Five Year Plan(2007-2012) Vol. 1, Oxford University Press, New Delhi

[24] Pulin B Nayak (2016): "Revisiting India's Growth and Development", Economic and Political Weekly, Vol. 51, Issue No. 34, 20th August 2016

[25] Reserve Bank of India (2013): "Committee on Comprehensive Financial Services for Small Businesses and Low Income Households-A Report "(Chair-Nachiket Mor), December

[26] Shivali: 2014 "Unorganized Workers Social Security Act, 2008; Issues and Challenges, Indian Labour Journal, January

[27] Thomas Picketty (2014): Capital in the Twenty First Century,
The Belknap Press of Harvard University Press, Cambridge, Massachusetts London, England

[28] T Prabhakar Reddy and Shashi Bhushan (2004): A Moving into Poverty Syndrome; Debt and Differentiation in Small Farm Economies-A Causal Study of Farmers' Suicides in Andhra Pradesh (Report); PSAMU, Society for Elimination of Rural Poverty, Government of Andhra Pradesh, Hyderabad

[29] T Prabhakar Reddy (2016); "Inequality and Institutionalizing Civil BRICS Process" The IndianExpress, October 17, http://indianexpress.com/article /blogs/inequality-and-institutionalizing-civil-brics-process3087756/

[30] T Prabhakar Reddy (2007); "Pattern of Health Expenditure and Utilization of Health Care Services in Andhra Pradesh, India; A Closer Examination “, paper presented in International Conference on Social Sciences, Honolulu, Hawaii, USA during 28 May-1June (Conference Proceedings)

[31] United Nations, 2015, The Worlds Women 2015: Trends and Statistics, New York: United Nations, Department of Economic and Social Affairs, Statistics Division.

[32] World Bank (2007): Informality: Exit and Exclusion, Washington; World Bank

[33] World Bank (2016): Poverty and Shared Prosperity 2016; Taking on Inequality

[34] World Bank (2011): Social Protection for A Changing India, Vol.1, Washington, DC USA

[35] World Social Protection Report, 2017-19, Universal Social Protection to Achieve the Sustainable Development Goals, ILO, Geneva, 2017

[36] World Employment Social Outlook, Trends 2019, International Labour Organization, Geneva

[37] Women and Men in the Informal Economy, A Statistical Picture, International Labour Organization, Geneva, 2018 